\title{
水中油滴型エマルション調製のための ポリマーマイクロチャネルの親水化
}

\author{
劉 海傑, 中嶋光敏 ${ }^{\$}$, 西 泰治*, 木村俊範** \\ (独)食品総合研究所 \\ * 株式会社クラレつくば研究所 \\ ** 筑波大学生命環境科学研究科
}

\section{Hydrophilic Modification of Polymer Microchannel for Preparation of Oil-in-Water Emulsions}

\author{
Haijie Liu, Mitsutoshi Nakajima ${ }^{\S}$, Taiji Nishi* and Toshinori Kimura** \\ National Food Research Institute, 2-1-12 Kannondai, Tsukuba, Ibaraki 305-8642 \\ * Tsukuba Research Laboratories, Kuraray Co., Ltd., 41 Miyukigaoka, Tsukuba, Ibaraki 305-0841 \\ ${ }^{* *}$ Graduate School of Life and Environment Sciences, University of Tsukuba, \\ 1-1-1 Tennodai, Tsukuba, Ibaraki 305-8572
}

\begin{abstract}
Microchannel (MC) emulsification is a novel technique for preparing monodispersed emulsions. Recently, we fabricated a new type of MC plate using polymer materials instead of the silicon materials used for conventional MC emulsification, and reported that monodispersed water-in-oil (W/O) emulsions were successfully prepared using an acrylic polymer MC (PMC) plate with hydrophobic properties. In this study, we modified the PMC surface with poly-2-methacryloxyethyl phosphorylcholine butyl methacrylate (Lipidure-PMB) and poly-ethylvinylalcohol (Exceval) coatings by $\mathrm{SiO}_{2}$ spattering and $\mathrm{SiO}_{2}$ vacuum deposition before producing oil-in-water $(\mathrm{O} / \mathrm{W})$ emulsions. Experimental results showed that the average droplet diameter and coefficient of variation were $35.7 \mu \mathrm{m}$ and $27.0 \%$ when the emulsion was prepared using a Lipidure-PMB coated PMC plate, with a polydispersed droplet diameter distribution ; $24.3 \mu \mathrm{m}$ and $3.8 \%$ when prepared using an Exceval-coated PMC plate, with a monodispersed droplet diameter distribution ; and 23.7 $\mu \mathrm{m}$ and $4.2 \%$ when prepared using a $\mathrm{SiO}_{2}$ vacuum deposition PMC plate, also with a monodispersed droplet diameter distribution. When $\mathrm{SiO}_{2}$ spattering was used, however, the hydrophilic $\mathrm{SiO}_{2}$ film came off the plate surface during the emulsification process, and the channel was wetted by the dispersed phase, with the result that preparation of a monodispersed $\mathrm{O} / \mathrm{W}$ emulsion was impossible. Furthermore, we investigated the resistance to sonic treatment of modified PMC plates, and it was found that the PMC plate modified by $\mathrm{SiO}_{2}$ vacuum deposition demonstrated the strongest resistance to sonic treatment.
\end{abstract}

(Received Mar. 28, 2005 ; Accepted Sep. 12, 2005)

10 年前に我々は血液レオロジー計測に用いられている シリコンマイクロチャネル $(\mathrm{MC})$ を応用して, 単分散エマ ルションを作製することのできる $\mathrm{MC}$ 乳化法を提案し た1). MC 乳化法とは MC を介して分散相液体を連続相液 体中に送り込むことにより，単分散のエマルションを作製 する方法である。 $\mathrm{MC}$ 乳化法は界面張力により液滴が自発 的に形成するので, 従来の機械的乳化法と比べて, エネル ギーロスが非常に少ない223). また, エマルション液滴の粒

テ305-8642 茨城県つくば市観音台 2-1-12

* $\mathbf{7} 305-0841$ 茨城県つくば市御幸が丘 41

***305-8572 茨城県つくば市天王台 1-1-1

$\S$ 連絡先 (Corresponding author), Tel : 029-838-8014

Fax : 029-838-7996 e-mail : mnaka@affrc.go.jp
度分布が狭く, 粒径のコントロールが可能であること, 単 相・多相エマルションのみならず, 機能性エマルション （マイクロカプセル，ベシクル，高分子微粒子）の作製屯可 能であることが注目されている(4) 7). シリコンマイクロ チャネルを用いた実験室規模の応用が広がりつつあるが, 材料と加工コストが高く, また，割れやすく取り扱いに注 意を要するなどの問題がある ${ }^{8) 9}$. そこで, 我々は, 材料コ ストが単結晶シリコンの 100 分の 1 程度のアクリル樹脂を 利用して平板型ポリマーマイクロチャネル (PMC) を作製 した。 PMCを用いたエマルションの調製，エマルション 作製特性に及ぼす各パラメータの影響解析，さらに従来の シリコン MC 乳化との比較などについて検討した ${ }^{10111)}$ 。 そ 
の結果，単分散の W/O エマルションを調製することが可 能で, 变動係数がシリコン $\mathrm{MC}$ 乳化と同程度であった。ま た, 分散相の圧力, 連続相の粘度, チャネルの深さ, 長さ が液滴作製に大きく影響を与えることが示された ${ }^{10) 11)}$.さ らに, PMC 基板は耐アルカリ性を有し, 洗浄の際, アルカ リ洗剤の使用が可能であることがわかった ${ }^{10)}$ 。これは現在 問題となっている SPG（シラス多孔質ガラス）膜を用いた 膜乳化やシリコン $\mathrm{MC}$ 乳化プロセスでの膜やチャネル基 板の洗浄, 再生の問題を解決できることが期待される.

上記のように, PMC 基板は疎水性を有し, 単分散 $\mathrm{W} / \mathrm{O}$ エマルションの作製が可能であるが，親水化による $\mathrm{O} / \mathrm{W}$ エマルションの作製が課題としてあげられる. PMC 基板 への親水化処理は， $\mathrm{O} / \mathrm{W}$ エマルションの作製だけでなく, 血液チップ, 細胞培養プレートの血液通過性向上, 気泡混 入防止などにも応用が考えられる。プラスチック表面の濡 れ性を改質する技術は, 化学的処理技術, 物理的処理技術 に大別される. 化学的処理技術としては, 薬品処理, 溶剤 処理, カップリング剤処理, モノマーコーティング, ポリ マーコーティング, 蒸気処理, 表面グラフト化, 電気化学 的処理などがあげられる．物理的処理技術としては，紫外 線照射処理, プラズマ接触処理, プラズマジェット処理, プラズマ重合処理, イオンビーム処理, 機械的処理等があ げられる12).

本研究ではコーティング，スパッ夕と真空蒸着の 3 種類 の方法により PMC の親水化処理を行い, 得られた親水化 基板を用いて， O/W エマルションの調製を試みた。また， 超音波にかけて洗浄を行う必要があると考えて, 親水化膜 の超音波耐性について検討した。

\section{実 験 方 法}

\section{1. 実験材料}

コーティング材料は 2 種類を選んだ。細胞膜を構成する フォスファチジルコリンの極性基と同一の構造をむつ 2メタクリロイルオキシエチルホスホリルコリン（以下 $\mathrm{MPC}$ と略, 親水性) とブチルメタクリレート（疎水性）を 共重合した水溶性ポリマー Lipidure-PMB（日本油脂, 東 京), ビニルアルコールとエチレンを共重合した水溶性ポ リマーエクセバール（クラレ, 倉敷）を用いた. Lipidure$\mathrm{PMB}$ とエクセバールの構造を Fig. 1 に示す. O/W エマル ション調製の乳化実験において, 連続相には純水を, 分散 相には大豆油 (和光純薬, 大阪) を, 界面活性剂には $1.0 \mathrm{wt}$ \%ドデシル硫酸ナトリウム（SDS, 純度 $>95 \%$, 和光純薬, 大阪）を用いた。

基板における水滴の接触角は全自動界面張力計（PD-W, 協和界面科学, 埼玉）により測定した。 各測定は常温で, 滴下 30 秒後に行った.

スパッ夕装置は SV（アルバック，東京）を，真空蒸着装 置は HP-1010F (アルバック, 東京) を用いた. 基板の超音

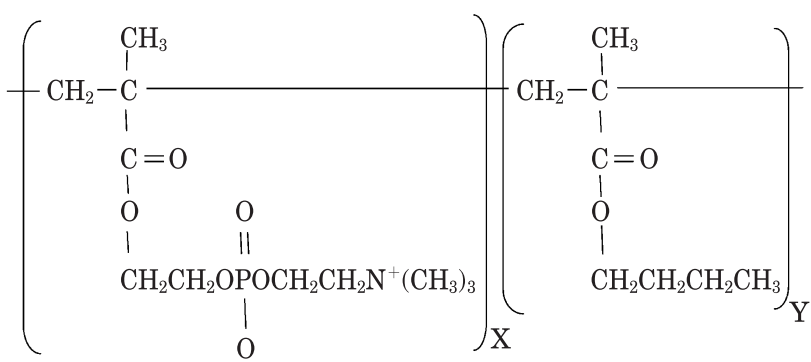

A<smiles>CCCCCCO</smiles>

B

Fig. 1 A) Chemical structure of Lipidure-PMB (poly-2methacryloxyethyl phosphorylcholine butylmethacrylate). B) Chemical structure of Exceval (poly-ethylvinylalcohol)

波処理は超音波洗浄機 US-3（アズワン，大阪）を用いた.

\section{2. 実験方法}

コーティング処理はスピンコート法（円盤上に設置した 基板に原料溶液をのせ，円盤を回転させることにより均一 な膜を形成する技術）にしたがって行った（スピンコー ター: $1 \mathrm{H}-360 \mathrm{~S}$, ミカサ, 東京). 親水化度は基板に対する 水滴の接触角により評価した。予備実験において, Lipidure-PMB 濃度が 0.5 wt \% ，エクセバール濃度が 5.0 $\mathrm{wt} \%$ であるとき，それぞれの接触角が最も低かったので, コーティング液濃度を $0.5 \mathrm{wt} \%$ (Lipidure-PMB)， $5.0 \mathrm{wt}$ \%（エクセバール）にした.

スパッ夕と真空蒸着による親水化処理の手順を Fig. 2 に示す. $\mathrm{SiO}_{2}$ をターゲット物質に用いた。 親水化処理品 は, 表面の光量をアップさせるべく, また, $\mathrm{SiO}_{2}$ とアクリ ル表面の接着性を改善するため, アルミニウム（A1, 200 $\mathrm{nm}$ ）を蒸着した上に，スパッ夕や真空蒸着を行った。 ス パッ夕処理, 真空蒸着による $\mathrm{SiO}_{2}$ 膜の膜厚については, そ れぞれ，平坦なガラス板の一部をテープでマスキングをし ておき, その表面に $\mathrm{SiO}_{2}$ 膜を堆積させ, 膜堆積面とマスキ ング剥離部分に精密接触針を走らせ，その段差の測定より 求めた。

乳化実験が終了後，PMC 基板の洗浄は次の 2 種類の方 法にしたがって行った。

(1) 超音波未処理: MC 基板を洗剂（クリーンエース, アズワン，大阪）の入った純水に 1 時間以上浸漬して，そ れから純水に 1 時間浸漬した。 その後, 常温乾燥し, 次の 実験まで保管した。

(2) 超音波処理 : MC 基板は洗剂（クリーンエース，ア ズワン, 大阪）の入った純水で 20 分，純水で 20 分，超音 波洗浄機内（VS-100 III SUNPAR, アズワン, 大阪) で洗浄 
を行った. その後, 常温乾燥し, 次の実験まで保管した.

\section{3. $\mathrm{PMC}$ 基板と $\mathrm{MC}$ 乳化装置}

$\mathrm{PMC}$ 基板の概念図, 電子顕微鏡写真および $\mathrm{MC}$ 乳化装 置の構成を Fig. 3 に示す。基板の材質はアクリル（グレー ド：パラペット GH-S, MFR-10, クラレ, 倉敷）であり, サイズが $22.5 \mathrm{~mm}$ (長さ) $\times 8 \mathrm{~mm}$ (巾) $\times 1.3 \mathrm{~mm}$ (厚さ) で ある (Fig. $3 \mathrm{~A}$ ). チャネル幅は $10 \mu \mathrm{m}$, 深さ $5 \mu \mathrm{m}$, 長さ 150 $\mu \mathrm{m}$, テラス長さ $15 \mu \mathrm{m}$ である (Fig. $3 \mathrm{~B}$ ). Fig. $3 \mathrm{C}$ に示す

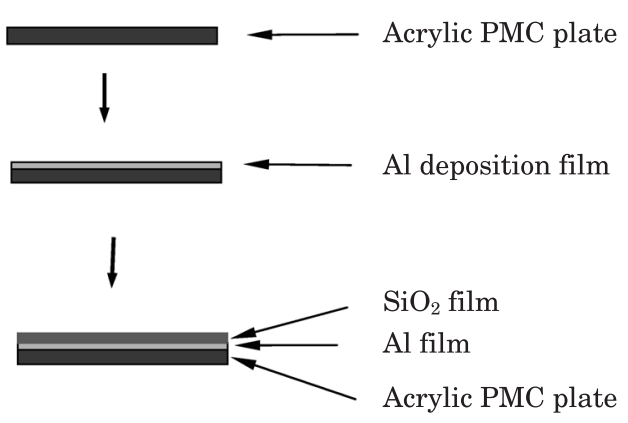

Fig. 2 Flowchart of sputtering or vacuum deposition treatment
ように，基板を光学研磨のガラス板に圧着させ，乳化専用 のステンレススチール製モジュールに固定した。分散相は リザーバーを用いて，また連続相はシリンジポンプ（Model 11, Harvard Apparatus. Inc., Massachusetts, USA）を用 いて，それぞれシリコンチューブをとおしてモジュールに 供給された。倒立金属顕微鏡（TS-V, 中央精機, 東京) と CCD カメラ（HV-C20M，日立電子，東京）を利用すること で, 乳化の様子はモニターでリアルタイムの観察が可能で ある.ビデオ（HM-DR10000, JVC, 横浜）によって画像を 録画してさらにパーソナルコンピューターに取り込むこと により液滴径, 变動係数の算出を行った。

\section{実験結果および考察}

1. コーティング $\mathrm{PMC}$ 基板を用いた $\mathrm{O} / \mathrm{W}$ エマルショ ンの調製

Table 1 に示すように, 0.5 wt\% の Lipidure-PMB で コーティングした PMC 基板に対する水滴の接触角は $16.8^{\circ}$ で, $5.0 \mathrm{wt} \%$ のクセバールでコーティングした $\mathrm{PMC}$ 基板の接触角は $56.3^{\circ}$ であった。

分散相には大豆油, 連続相には水, 界面活性剂には SDS を用いて $\mathrm{O} / \mathrm{W}$ エマルションの調製を行った。 分散相をリ
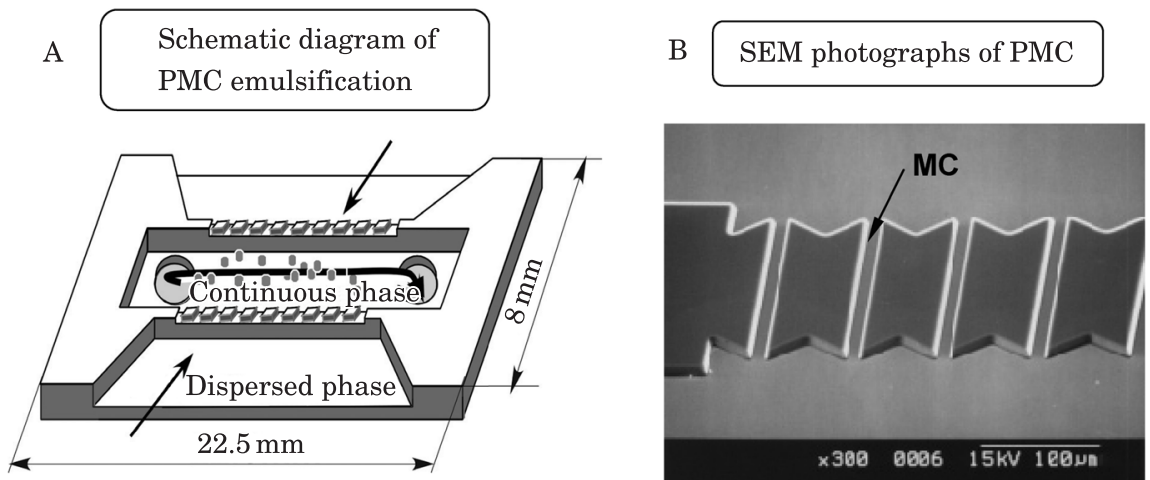

C

MC emulsification and microscope video system

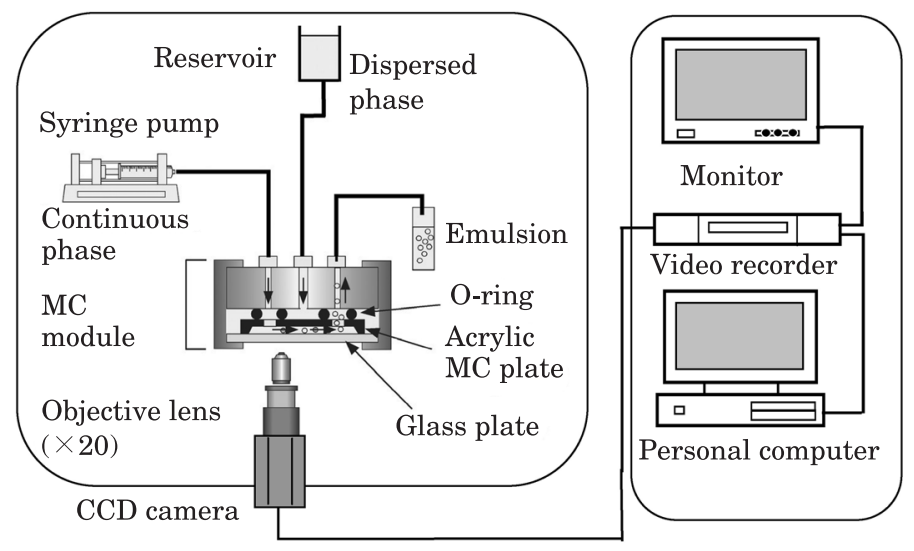

Fig. 3 Experimental installation 
ザーバー，連続相をシリンジポンプ（流量 $2 \mathrm{~mL} \mathrm{~h}^{-1}$ ) によ り供給した. Lipidure-PMB でコーティングしたPMCを 用いた乳化の様子を Fig. 4 A に示す。分散相がチャネルを 出てテラスに入り, 井戸部に流れ込もうとしたところ, 一 部のチャネル内の分散相が切断して液滴を形成するが，い くつかのチャネルが分散相により濡れてしまい, 巨大な液 滴が形成された。作製したエマルションの平均液滴径が
$35.7 \mu \mathrm{m}$, 変動係数が $27.0 \%$ であり, 単分散のエマルション が得られなかった (Fig. 4 B).

Lipidure-PMB と同じ条件下で $5.0 \mathrm{wt} \%$ エクセバール コーティングした PMC を用いて O/W エマルションを調 製してみた。乳化の様子と作製した液滴（大豆油滴）を Figs. 4 C, D に示す. 液滴が規則正しく形成し，チャネル濡 れは見られなかった。作製したエマルションの平均液滴径

Table 1 Contact angles of water droplets on PMC plate in air after hydrophilic modification

\begin{tabular}{lccc}
\hline \hline \multirow{2}{*}{$\begin{array}{l}\text { Hydrophilic } \\
\text { modification methods }\end{array}$} & \multirow{2}{*}{$\begin{array}{c}\text { Concentration } \\
\text { or film thickness }\end{array}$} & \multicolumn{2}{c}{ Contact angles (deg) } \\
\cline { 3 - 4 } PMB coating & $0.5 \mathrm{wt} \%$ & 16.8 & 70.1 \\
Exceval coating & $5.0 \mathrm{wt} \%$ & 56.3 & 56.7 \\
\multirow{2}{*}{ Sputtering } & $\mathrm{SiO}_{2}, 100 \mathrm{~nm}$ & 14.5 & - \\
& $\mathrm{SiO}_{2}, 500 \mathrm{~nm}$ & 14.5 & - \\
Vacuum deposition & $\mathrm{SiO}_{2}, 100 \mathrm{~nm}$ & 35.9 & - \\
\hline
\end{tabular}
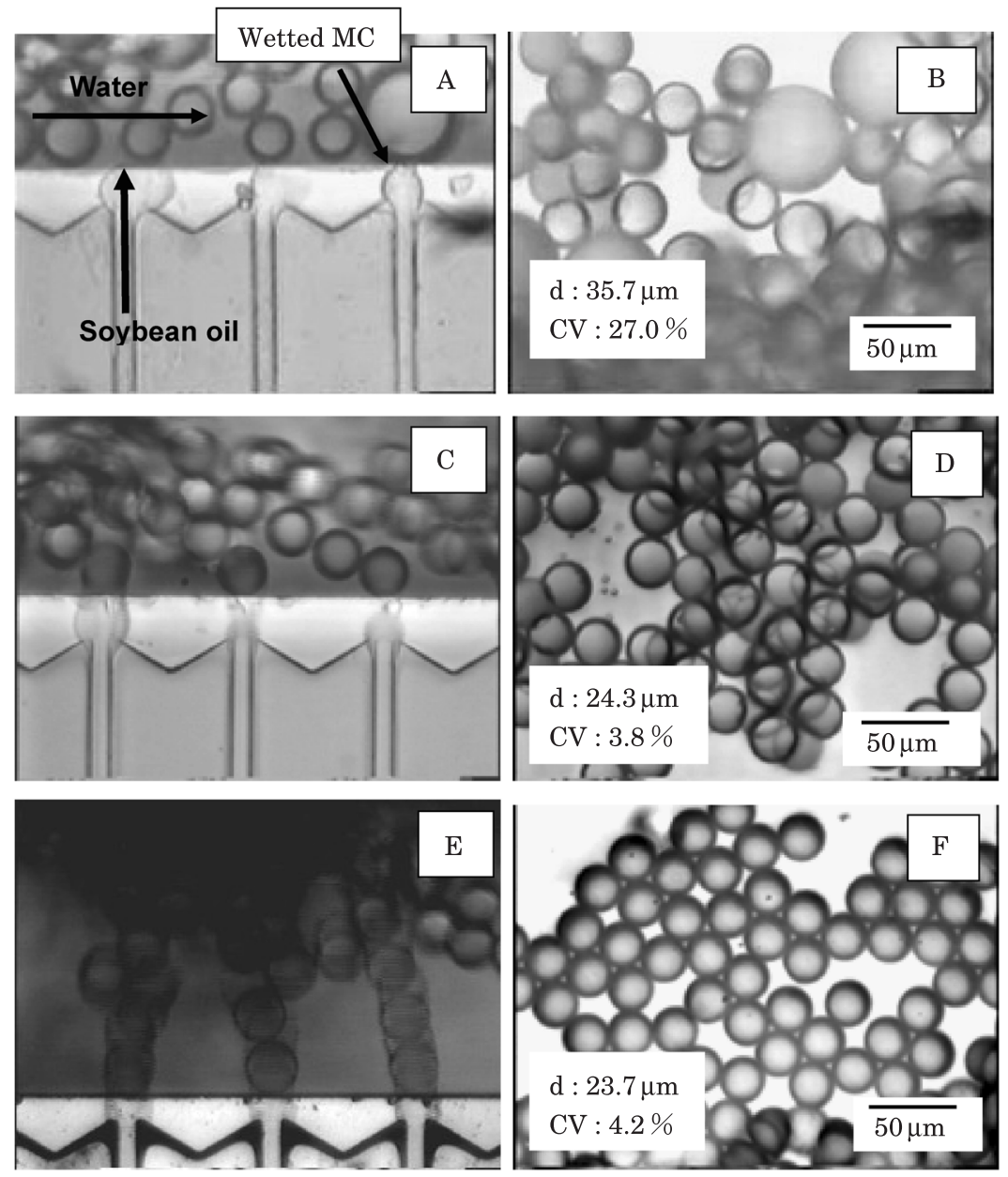

Fig. 4 Microscope photographs of PMC emulsification process. A, B) PMC surface was modified by PMB coating. C, D) PMC surface was modified by Exceval coating. E, F) PMC surface was modified by $\mathrm{SiO}_{2}$ vacuum deposition. A, C, E) Emulsification processes observed at real time. B) Prepared polydispersed oil droplets. D, F) Prepared mono-dispersed oil droplets. 

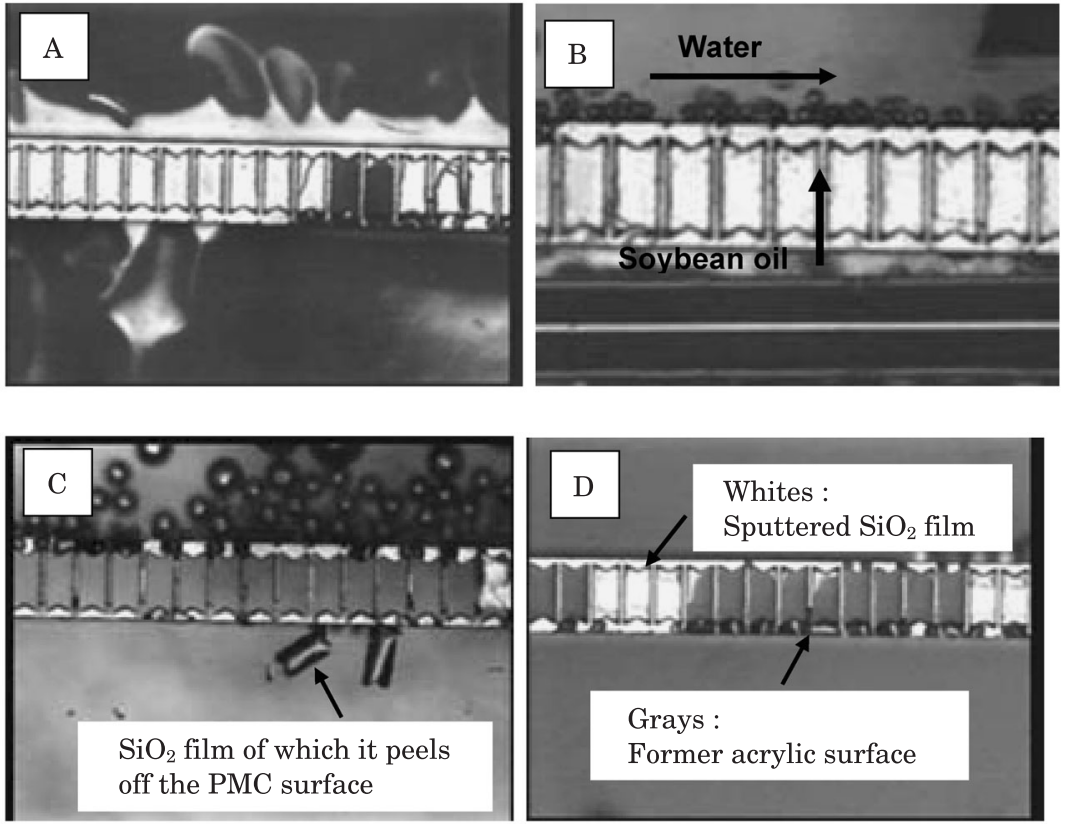

Fig. 5 Microscope photographs of PMC emulsification process (PMC surface was modified by $\mathrm{SiO}_{2}$ sputtering). A) Before setting PMC plate in the continuous phase. B, C) Emulsification processes observed at real time. D) PMC plate after one run of emulsification.

が $24.3 \mu \mathrm{m}$, 変動係数が $3.8 \%$ で単分散性に優れていた.

乳化後, PMC 基板での水滴の接触角を測定したところ, Table 1 に示されるように, Lipidure-PMB でコーティン グした基板の接触角は $70.1^{\circ}$ となり，ほぼ未処理時の値に 戻った。一方，エクセバールでコーティングした基板の接 触角は 56. $7^{\circ}$ でほとんど変化がみられなかった．Fig. 1 の Lipidure-PMB の構造式からわかるように, 疎水性のブチ ルメタクリレートが疎水性のアクリル表面に付着し, 親水 性の MPC がその上に並んで，基板に親水性を与えるわけ である．乳化実験中，ブチルメタクリレートとアクリル基 板の結合の程度が十分ではなく, 親水化膜が連続相 (1.0 wt \% SDS）へ溶出し，基板表面が疎水性に戻ったため，分 散相により需れてしまったと考えられる。 それに対して, エクセバールは融点が高い $\left(70^{\circ} \mathrm{C}\right.$ 以上）ので，基板との結 合力が強く, 連続相への溶出がほとんど起こらないと考え られる。

2. スパッタ $\mathrm{PMC}$ 基板を用いた $\mathrm{O} / \mathrm{W}$ エマルションの 調製

Table 1 に示すように，スパッ夕処理した PMC 基板の 接触角は $14.5^{\circ}$ であり, 最も低い值を示した. まずスパッ夕 膜厚が $100 \mathrm{~nm}$ の PMC を用いた。チャネル部が分散相に より濡れてしまい, 油滴作製が不可能であった。これは, スパッ夕法による製膜において, $\mathrm{SiO}_{2}$ は，主に平らな表面 に付着し，チャネルとテラスの側面への付着が十分ではな く, チャネルの濡机が起こったと考えられる.

そこで，膜厚を $500 \mathrm{~nm}$ にして乳化実験を行った，ス パッ夕処理後, 乳化実験の前の PMC と乳化実験中の
PMC の画像を Fig. 5 A に示す. 実験開始前にすでにチャ ネル部に $\mathrm{SiO}_{2}$ 膜の剥離, また外端部にクラックが生じて いる.これは, $\mathrm{SiO}_{2}$ の膜厚を厚くしたことで, $\mathrm{PMC}$ と $\mathrm{SiO}_{2}$ 膜の熱膨張係数の違いに基づく応力が顕在化して, 金 属膜の剥離，平坦部のクラックが生じたと考えられる。こ の状態の基板を用いた乳化の様子を Figs. $5 \mathrm{~B}, \mathrm{C}$ に示す. 液滴作製が可能であったが，実験中にスパッ夕膜の剥離が 見られた。また，剥離した膜の破片が連続相中に残ってい た画像屯撮られた。乳化実駼終了後の PMC の様子を Fig. $5 \mathrm{D}$ に示す。ほとんどのスパッ夕膜が剥がれ，スパッ夕処 理した $\mathrm{PMC}$ は $\mathrm{O} / \mathrm{W}$ エマルションの作製に不適であるこ とがわかった。

3. 真空蒸着 $\mathrm{PMC}$ 基板を用いた $\mathrm{O} / \mathrm{W}$ エマルションの 調製

真空蒸着法により処理した PMC を用いて，上記と同一 実験条件下で乳化実験を行った。蒸着したPMC 基板の接 触角は $35.9^{\circ}$ であった（Table 1). スパッ夕処理基板と比べ ると接触角が高い。これは，スパッ夕処理では， $\mathrm{SiO}_{2}$ が分 子レベルで緻密に蒸着するのに比べて, 真空蒸着では, $\mathrm{SiO}_{2}$ が分子集合体として大きな単位で，ランダムに付着す るため, 親水性の程度が低く, 接触角は高くなったもの之 思われる。乳化実験の画像を Fig. $4 \mathrm{E}$ に示す．濡れや膜の 剥離はみとめられず，ほとんどのチャネルにおいて液滴形 成が規則正しく，単分散の $\mathrm{O} / \mathrm{W}$ エマルションの作製が可 能であった. 作製した液滴は平均粒径が $23.7 \mu \mathrm{m}$, 変動係数 が $4.2 \%$ であった（Fig. 4F). 前述したように，エクセバー ルコーティング基板の接触角は $56.3^{\circ}$ で, 真空蒸着基板と 
大きく異なったが，作製したエマルション液滴径はいずれ あ約 $24 \mu \mathrm{m}$ であり，ほとんど差が見られない，すなわち， 基板の表面がある程度の親水性を有し, 分散相による濡れ が起こらない条件であれば, 液滴径は基板の接触角にほと んど依存しないことがわかった。

\section{4. 親水化膜の超音波耐性}

上記の結果に基づき，単分散 $\mathrm{O} / \mathrm{W}$ エマルションの作製 に適用可能なエクセバールコーティングと真空蒸着処理の 2 種類の親水化 $\mathrm{PMC}$ 基板の超音波耐性を調べた。 エクセ バールコーティングの場合，乳化実験が終了後， PMC 基 板を実験方法 2 (2)に述べたように，洗剤の入った純水で 20 分, 純水で 20 分, 超音波洗浄機内で洗浄を行った. 洗浄 済みの基板を用いて, 乳化実験を行ったところ, 分散相に よるチャネルの濡れが観察され，単分散液滴の作製ができ なかった。 一方, 真空蒸着の場合, 超音波処理 400 分間 行った後の乳化実験においても, 単分散液滴の安定的な作 製が可能であり，超音波耐性を有し，安定性に優れている ことがわかった。

\section{要約}

アクリル $\mathrm{PMC}$ 基板に対して親水化処理と $\mathrm{O} / \mathrm{W}$ エマル ションの作製を試みた。 高分子コーティング，スパッタと 真空蒸着の 3 種類の親水化法を実施した。 その結果, 高分 子コーティング法の中で, エクセバールコーティングを施 した PMCを用いた場合，単分散の $\mathrm{O} / \mathrm{W}$ エマルションの 作製が可能であった。 また，スパッ夕法により処理した PMC は膜応力による剥離が生じて，エマルションの調製 に不適であった。さらに, $\mathrm{SiO}_{2}$ 真空蒸着法により処理した $\mathrm{PMC}$ 基板を用いて単分散の $\mathrm{O} / \mathrm{W}$ エマルションの作製が 可能であり，また，エクセバールコーティングと比べ，超 音波耐性に優れていることが示された.

本研究は, 農林水産省ナノテクノロジープロジェクトの 助成を受けた.

\section{文献}

1) Kawakatsu, T., Kikuchi, Y. and Nakajima, M., Regularsized cell creation in microchannel emulsification by visual microprocessing method, J. Am. Oil Chem. Soc., 74, 317-321 (1997).

2) Sugiura, S., Nakajima, M., Iwamoto, S. and Seki, M., Interfacial tension driven monodispersed droplet formation from microfabricated channel array, Langmuir, 17, 5562-5566 (2001).

3) Sugiura, S., Nakajima, M., Kumazawa, N., Iwamoto, S. and Seki, M., Characterization of spontaneous transformation-based droplet formation during microchannel emulsification, J. Phys. Chem. B, 106, 9405-9409 (2002).

4) Kobayashi, I., Nakajima, M., Tong, J., Kawakatsu, T., Nabetani, H., Kikuchi, Y., Shohno, A. and Satoh, K., Production and characterization of monodispersed oilin-water microspheres using microchannels, Food Sci. Technol. Res., 5, 350-355 (1999).

5) Sugiura. S., Nakajima, M., Ushijima, H., Yamamoto, K. and Seki, M., Preparation characteristics of monodispersed water-in-oil emulsions using microchannel emulsification, J. Chem. Eng. Japan. 34, 757-765 (2001).

6) Sugiura, S., Nakajima, M., Tong, J., Nabetani, H. and Seki, M., Preparation of monodispersed solid lipid microspheres using a microchannel emulsification technique, J. Colloid Interface Sci., 227, 95-103 (2000).

7) Sugiura, S., Nakajima, M., Itou, H. and Seki, M., Synthesis of Polymeric Microspheres with narrow size distributions employing microchannel emulsification, Macromol. Rapid Commun, 22, 773-778 (2001).

8) Soper, S.A., Henry, A.C., Vaidya, B., Galloway, M., Wabuyele, M. and McCarley, R.L., Surface modification of polymer-based microfluidic devices, Anal. Chim. Acta, 470, 87-99 (2002).

9) Becker, H. and Locascio, L.E., Polymer Microfluidic Devices, Talanta, 56, 267-287 (2002).

10) Liu, H.J., Nakajima, M. and Kimura, T., Production of monodispersed water-in-oil emulsions using polymer microchannels, J. Am. Oil Chem. Soc., 81, 705-711 (2004).

11） 劉 海傑, 中嶋光敏, 西 泰治, 木村俊範, ポリマーマイク ロチャネルを用いた油中水滴作製に及ぼす操作パラメー夕 㧍よびチャネル構造の影響; 日本食品工学会誌， 5，259266 (2004).

12）井手文雄，高分子表面改質，近代編集社，東京（1987）. (平成 17 年 3 月 28 日受付，平成 17 年 9 月 12 日受理) 